\title{
Affects of Female Directors on Firms Performance in Pakistan
}

\author{
Qaiser Rafique Yasser \\ Faculty of Economics and Business, University Malaysia Sarawak, Kota Samarahan, Malaysia \\ Email: qaiser_rafique1@hotmail.com
}

Received October 4, 2012; revised November 7, 2012; accepted November 15, 2012

\begin{abstract}
This study examined relationship between board gender diversity and its effect on firm performance, based on evidence from the Pakistan. We use empirical data on KSE 100 Index firms observed in 2008 to 2010. Twenty Five percent $(25 \%)$ of the sample firms have at least one woman in the boardroom and only $3.33 \%$ of the CEOs are female. In order to investigate the rapport of gender diversity in board on firm performance, two-stage least-squares estimation used, using Economic Valued Added (EVA) as performance measurement technique. Our results indicate that there is no significant relationship between board gender diversity on firm performance in Pakistan. This implies that the business case for board gender diversity is not supported for this particular sample.
\end{abstract}

Keywords: Corporate Governance; Firm Performance; Gender Diversity in Boardroom; Economic Value Added (EVA)

\section{Introduction}

Women representation in business management has been the focus of public debates from researchers, policy makers and investors more than 2 decades but in Pakistani context that is a new notion. The 21 st century workforce is typified by more women and employees with diverse ethnic backgrounds, alternative lifestyles, and intergenerational differences than in the past (Langdon, McMenamin \& Krolik [1]). Furthermore, executives have realized that the extent to which these demographic workforce changes are effectively and efficiently managed will impact organizational functioning and competitiveness (Von Bergen, Soper \& Parnell [2]). In European prospective, previously considered a communal issue and an issue of image, gender diversity is increasingly approached as a value-driver in organizational strategy and corporate governance, and as such has become a challenging concern in recent academic research. Positive performance effects of board gender diversity imply that a higher ratio of female directors in board will relate to increased firm value, productivity and profitability.

The relationship between board diversity and firm performance may occur through a firm's diversity reputation, such effects may also be manifested through heterogeneity at various organizational levels. Literature implies several reasons for including women members on a firm's board of directors. Increased diversity of board members may bring a diversified team of professionals, knowledge and information for the board to use in ful- filling its responsibilities in representing shareholders' interests (Burgess and Tharenou [3], Hillman, Canella and Harris [4]). According to the Daily, Certo, and Dalton [5] women make $60 \%$ of all purchases in the United States and, therefore, it is just good business to include women on board of directors. It indicates that female members are sensitive observer of the market and can bring a more realistic approach which can reflect the consumer point of view.

Ethical Investment Research Service (2004) exemplify that women board directors were less than 10 percent of the total number of directors of companies headquartered in Australia, the United Kingdom, Germany, France, Singapore, Hong Kong, Spain, Italy, and Japan. Only Norway (greater than 25 percent), where federal legislation requires all boards to have at least two women by 2006 and to have 40 percent women by 2008, and Sweden (almost 20 percent) had percentages of women directors greater than those in the United States.

In Pakistan, tryst of female directors as independent non-executive directors is not usually exist, but the females in board are those who belongs to the controlling family and due to the execution of the constitutional requirement by the company's ordinance. Various founders grasp their family female directorship only to seize the brawny hold of their family on business and to crack the predicament of inheritant division to the next generation.

The aim of this paper is to contribute the evidence on gender diversity in board and firm performance from Pakistan as until now most empirical research has fo- 
cused on US companies. Moreover, the paper will contribute to the scientific debate by applying a methodology that allows for correct analysis of the relationship between board gender diversity and firm performance. Analyzing this relationship is complicated as the direction of causality can be twofold; that is more female board directors may contribute to higher firm performance, but it might also be the case that better-performing firms tend to appoint more women on their boards. By taking this complication into account, the results of the analysis will be more robust and thus more reliable.

\section{Demographic Diversity}

Existing literature on diversity typically follows two general distinctions: 1) the observable (demographic) and; 2) the non-observable (cognitive). Examples of observable diversity are generally gender, age, race and ethnicity and examples of non-observable diversity are knowledge, education, values, perception, affection and personality characteristics (Maznevski [6], Milliken and Martins [7], Pelled [8], Boeker [9], Watson et al., [10], Kilduff, et al., [11], Petersen [12], Timmerman [13]). However, most research on diversity and its effects on performance focus on observable or demographic diversity.

This study considers demographic diversity as it directly reflects the increasing numbers of women directors in board representation, Hispanic, Black and Asian Americans entering into the management labour market (Conyon and Mallin [14]). There is research that suggests that diversity is increasing especially by gender. Daily et al. [5] in his study on Fortune 500 firms, indicates that women have made significant progress in terms of assuming seats on boards of directors, but have not in terms of taking CEO positions. Bilimoria [15] reports that even though the number of female board members is increasing slightly, few companies actively recruit females and there is still sex bias, stereotyping and tokenism on boards where women serve. Mattis [16] concludes that women board members are increasing in numbers but the changes are small and incremental.

\section{Theoretical Background and Recent Empirical Findings}

Within a corporate governance framework, the composition of corporate boards is crucial to aligning the interest of all stakeholders, to providing information for monitoring and counseling, and to ensuring effective decision-making (Becht, Bolton and Röell [17], Hermalin and Weisbach [18]). Gender diversity, together with board size, age dispersion and the share of directors chosen by the employees, all relate to board decision-making processes (Bøhren and Strøm, [19]). Whether board diversity influences firm performance in a positive or negative way, however, is theoretically undetermined a priori. In more general terms, Becht et al. [17] conclude that the formal literature on board design is "surprisingly thin". At the same time according to our knowledge this is first study on gender diversity and its effects on firm performance in Pakistan.

A major argument in support of management diversity is that a more diverse board of directors may take decisions while considering a wider range of alternatives. Carter, Simkins and Simpson [20] and Carter, D'Souza, Simkins and Simpson [21] enumerate several positive propositions of the business case for board gender diversity, among which this is a central one. Within the "upper echelons" theory, diverse top management teams relate to more creative idea generating, and are thus linked to more innovative organizations (Jackson, [22]).

Smith, Smith and Verner [23] intricate that women directors may better understand particular market conditions than men, which may bring more creativity and quality to board decision-making. Smith et al. [23] also argue that a more gender diverse board may generate a better public image of the firm and, through this, improve firm performance. In addition it is possible that the external talent pool for board members increases once women have been appointed to particular executive positions. Furthermore, their research shows that the number of female top managers may influence positively the career development of women in lower positions, thus boosting firm productivity directly as well as indirectlyi.e. by enlarging the internal pool of candidates for top positions.

However, while the "management friendliness hypothesis" may hold for boards in general, it may be less true of boards having women directors. Women directors may not be fully assimilated into traditionally male dominated boards of directors. There is, for example, evidence that female directors differ from their male counterparts in several ways. Female directors tend to have advanced degrees, and are more likely to come from non-business careers as compared to male directors (Hillman, Canella \& Harris, [4]). Bilimoria and Piderit [24] found that male directors were favored for membership on three types of committees: compensation committee, executive committee, and finance committee. On the other hand, female board members were favored for another type of committee, namely public affairs committee. These results were observed after controlling for the effects of experience.

Zahra and Stanton [25] examined the relationship between gender diversity and firm financial performance. They worked with 100 Fortune 500 firms and they used return on equity (ROE), profit, earnings per share, dividend per share and profit margin on sales as performance 
variables. Zahra and Stanton did not find a statistically significant relationship between gender diversity and firm financial performance. Carter, Simkins and Simpson [20] examined the relationship between board genderdiversity and firm value for the Fortune 1000 firms. Using Tobin's $\mathrm{Q}$ as a measure of firm value, they found statistically significant positive relationships between the percentage of women on the board of directors and firm value as well as presence of women on the board of directors and firm value.

The results from studies conducted on US seem to be predominantly positive, European evidence appears to be mixed. Rose [26] used a sample of Danish firms listed on the Copenhagen Stock Exchange during 1998-2001, and found that female board representation had no impact on firm performance. Smith et al. [23] in a panel data study of 2500 of the biggest Danish firms showed that the share of women among top executives and on boards of directors tended to have a significantly positive effect on firm performance, controlling for firm characteristics, as well as for the direction of causality. Furthermore their results revealed that the positive performance effects were mainly accounted for by female managers with university education, and were also related to female board members elected by the staff. Francoeur, Labelle and Sinclair-Desgagné [26] used the sample of $500 \mathrm{Ca}-$ nadian firms during the year 2001 to 2004 (Four Years) and found that firms operating in complex environments generate positive and significant abnormal returns of $0.17 \%$ monthly when they have a high proportion of female directors. The gender diversity leads to more diverse knowledge bases and perspectives that are needed to develop and evaluate solutions to complex problems. Randøy, Thomsen and Oxelheim [27] investigated the effect of board diversity on corporate performance, examining a sample of the largest companies from Denmark, Norway and Sweden, and found no significant gender diversity effect. Bøhren and Strøm [19], studying a sample of Norwegian listed non-financial firms, seem to be the only researchers who found a significantly negative association between board gender diversity and firm performance. Kang, Ding and Charoenwong [28] investigated the stock market reaction to female directors in an Asian context by using a sample of 45 Singaporean firms. They found that public listed firms experience positive abnormal returns when they announce the appointment of female members in the board. The stock market reaction is more positive when the female directors are appointed for a non-CEO executive or independent board position.

Investigating the role of gender has also been extended to the complicated context of mergers and acquisitions (M\&A). However, evidence is still very limited. Levi, Li and Zhang [29] examined the effects of female CEOs and corporate directors on the pricing and abnormal returns on $403 \mathrm{M} \& \mathrm{~A}$ in the US. They showed that the presence of a female CEO in the bidding company and independent female directors in the target company reduced the bid premium paid, and were associated with lower cumulative abnormal returns in the target companies during the period of announcement of the M\&A event. Sudarsanam and Huang [30] studied a sample of more than 2500 acquisitions in the US and documented that the market initially responded favorably to M\&A deals concluded by female CEOs, however, this was reversed in the long run. In fact, Sudarsanam and Huang concluded that "risky corporate acquisitions undertaken by female CEOs destroy shareholder's value in the long run" ( $p$. 21).

This study use EVA as firm performance measure, Economic value added is ones of the performance measurement that suitable with the value based management. This terminology introduce by Stern Seward Management Service, the consultant firm from USA. EVA indicates that the firm has value creation from the investment in the current period. Positive EVA reflect that a company able to create the value to the shareholder (Utama, [31]). It is used to evaluate economic value, assess funds and efficiently allocate resources, and uses adjustment items to reflect true economic value of a firm. Therefore, it is also a performance measurement tool (Mohanty [32], Copeland and Dolgoff [33], Kaur and Pal [34], O'byrne and Young [35]). Additionally, EVA is a supplying chain strategy (Pohlen and Coleman [36]). Although the using of EVA become popular, traditional accounting performance like return on asset, return on equity, sales growth, still are used to measure the performance of company by investor. Investors with long-run orientation still use accounting performance as a consideration for investment decision.

\section{Sample and Data}

Our sample comprised KSE-100 Index companies for three years 2008 to 2010. Companies were excluded in case of non availability of data or missing data. According to the Karachi Stock Exchange official brochure "The KSE-100 Index was introduced in November 1991 with base value of 1000 points. The KSE-100 Index comprises of 100 companies selected on the basis of sector representation and highest market capitalization, which captures over $90 \%$ of the total market capitalization of the companies listed on the Exchange. Out of the following 33 Sectors, 32 companies are selected i.e. one company from each sector (excluding Open-End Mutual Fund Sector) on the basis of the largest market capitalization and the remaining 66 companies are selected on the basis of largest market capitalization in descending order. This is a total return index i.e. dividend, bonus and 
rights are adjusted."

A sample size of 100 firms was taken in the start. But due to availability of data, final sample of 90 firms were taken, which were having complete data of three years period from 2008 to 2010. Data on required variables is collected through secondary sources. Data on Corporate Governance internal mechanism are collected through company information page, compliance with the code of corporate governance report, directors' profiles and directors' report to the shareholders. Data related to financial part of the study is collected from financial statement part of Annual Reports. Figure 1 indicates the number of female directors toward proportionate to the male directors in the sample companies.

\section{Methodology}

The solemn complication in this study is the relationship between board gender diversity and firm performance is that finding a correlation does not imply causality. The direction of causality can go both ways - meaning either that gender diversity leads to higher performance, or that high performing companies tend to employ a more gender diverse workforce-and can thus imply joint endogeneity of the variables board gender diversity and firm performance.

Following Carter et al. [20] and Marinova et al. [37] we estimated the below-given system of simultaneous Equations (1) and (2).

$$
\begin{aligned}
& \text { Firm Performance }= \\
& \alpha_{0}+\alpha_{1} \text { Board Gender Diversity }+\Sigma_{\alpha x}+\epsilon \\
& \text { Board Gender Diversity }= \\
& \beta_{0}+\beta_{1} \text { Firm Performance }+\Sigma_{\beta z}+v
\end{aligned}
$$

where $x$ and $z$ are vectors of control variables.

For the interpretation of results, a significant positive coefficient estimate $\left(\alpha_{1}>0\right)$ will confirm our research hypothesis. If our hypothesis is rejected, firm performance may either be negatively affected by board gender diversity (in that case the estimated coefficient of $\alpha_{1}$ is negative) or the presence of females on board of directors has no association with firm performance (in that case the estimated coefficient of $\alpha 1$ is zero or insignificant).

\section{Variables}

\subsection{Firm Performance}

Economic Value Added was popularized by Stern Stewart \& Company, and is based on a company's accounts. Its mechanism which is accounting based simplifies to the following relationship:

$\mathrm{EVA}=$ Operating Profit after tax -(Operating expenses - Invested Capital)

where "Financial requirements" is calculated as defined

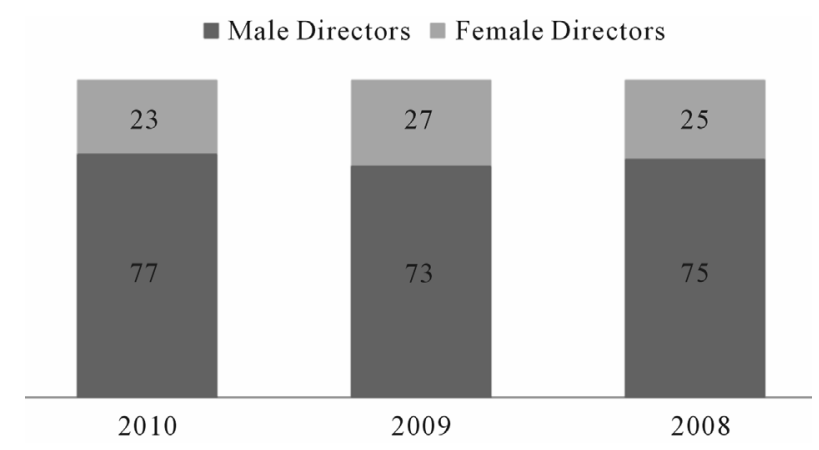

Figure 1. Male and female directors in sample.

capital multiplied with a suitable weighted average cost of capital (WACC).

Stewart has identified several errors made in accounting from investors' perspective. He advises that the errors be adjusted to stimulate cash flow. Examples of situations requiring adjustment are inventory costing and valuation, depreciation, revenue recognition, and capitalization and amortization of R\&D, marketing, restructuring charges and acquisition premiums.

\subsection{Board Gender Diversity}

Board gender diversity is measured in three ways: 1) Percentage of women directors on the total members in board; and 2) Dummy variable indicating 1 if there is at least one woman on the board, or zero otherwise; 3) Dummy variable indicating 1 if $\mathrm{CEO}$ is female, or zero otherwise.

\subsection{Control Variables}

Board size has been taken as first control variable in this study. Hermalin and Weisbach [13] argue that corporate governance research revealed the existence of a predominantly negative association between board size and firm performance, whereas an inverse association between board size and Tobin's Q was found by Yermack [38] and Carter et al. [20].

Secondly, firm size was included as control variables. Firm size is measured by the natural logarithm of the net assets of the company.

All variables used are summarized in Table 1.

\section{Analysis}

The companies in our sample have a total of 2364 board positions and 122 women occupy on director seats. The majority of female directors held non-executive (supervisory) role (112); there were only 10 female executive directors. The percentage of companies with at least one female director in our total sample is $25 \%$ in $2008,27 \%$ in 2009 and $23 \%$ in 2010 with an average of $25 \%$. Table 2 presents descriptive statistics of key variables from 
sample. The mean of board size is 8.76 , with a minimum of 4 and a maximum of 15 members. The average share of women on board is $5.8 \%$ and the highest percentage of women on the board found is $57.14 \%$. The means value of the companies having female CEO is 0.037 and 4 companies in 2008, 3 companies in 2009 and 3 companies in 2010 having female CEO. The mean of EVA is -75.93, minimum EVA of the sample companies is -1212.30 and maximum EVA value is 465.00 with a range of 1677.30 and standard deviation of 203.61, Skewness is -3.005 and Kurtosis 10.710 . Firm size hav- ing means value of 5.37 and standard deviation of 1.60 .

Table 3 (Paired sample t-test) indicates the high value of standard deviation of Female CEO Status, presence of female directors in board and higher proportionate of female directors to male directors with EVA. The test statistics reveal that the female CEO correlation is slightly increased with presence of female in board only by 0.24074 percent, and correlation of female presence in board is increased significantly with proportionate of female with male by 5.52335 percent.

The results of Pearson correlation (Table 4) indicate

Table 1. Summary of variables.

\begin{tabular}{|c|c|c|}
\hline \multicolumn{3}{|r|}{ Governance Variables } \\
\hline (A) & Female CEO (FCEO) & Dummy variable indicating 1 if CEO is female, or zero otherwise \\
\hline (B) & Female Proportionate (FEPOR) & Percentage of women directors on the total members in board \\
\hline (C) & Gender Diversity (GEDIV) & Dummy variable indicating 1 if there is at least one woman on the board, or zero otherwise \\
\hline \multicolumn{3}{|r|}{ Performance Variable } \\
\hline (D) & Economic Value Added (EVA) & $\begin{array}{l}\text { Net Operating Profit After Taxation (NOPAT) } \\
\text { Weighted average cost of capital (WACC) } \\
\text { Invested Capital (IC) } \\
\text { EVA = NOPAT }- \text { (WACC } \times \text { IC) } \\
\text { IC = Total Equity }- \text { Total Liabilities }- \text { Non Interest bearing current liabilities }\end{array}$ \\
\hline \multicolumn{3}{|r|}{ Control Variables } \\
\hline (E) & Board Size (BSIZE) & Total number of directors having board membership \\
\hline (F) & Firm Size (FRSIZE) & Natural Logarithm of Total Assets \\
\hline
\end{tabular}

Table 2. Descriptive statistical.

\begin{tabular}{|c|c|c|c|c|c|c|c|c|c|c|}
\hline & \multirow{2}{*}{ Range } & \multirow{2}{*}{ Minimum } & \multirow{2}{*}{ Maximum } & \multirow{2}{*}{ Mean } & \multirow{2}{*}{ S.D } & \multirow{2}{*}{ Variance } & \multicolumn{2}{|c|}{ Skewness } & \multicolumn{2}{|c|}{ Kurtosis } \\
\hline & & & & & & & Statistic & Std. Error & Statistic & Std. Error \\
\hline FCEO & 1 & 0 & 1 & 0.04 & 0.189 & 0.036 & 4.930 & 0.148 & 22.475 & 0.295 \\
\hline GEDIV & 1 & 0 & 1 & 0.28 & 0.449 & 0.201 & 0.998 & 0.148 & -1.012 & 0.295 \\
\hline FEPOR & $57.14 \%$ & $0.00 \%$ & $57.14 \%$ & $5.80 \%$ & $11.17 \%$ & 124.68 & 2.274 & 0.148 & 5.585 & 0.295 \\
\hline FMSIZE & 6.56 & 2.46 & 9.01 & 5.37 & 1.60 & 2.571 & 0.538 & 0.148 & -0.922 & 0.295 \\
\hline BSIZE & 11 & 4 & 15 & 8.76 & 3.125 & 9.764 & -0.678 & 0.148 & -1.327 & 0.295 \\
\hline EVA & 1677.30 & -1212.30 & 465.00 & -75.93 & 203.61 & 41457.98 & -3.005 & 0.148 & 10.710 & 0.295 \\
\hline
\end{tabular}

Table 3. Pair analysis of independent variables with EVA.

\begin{tabular}{|c|c|c|c|c|c|c|c|c|}
\hline & \multicolumn{5}{|c|}{ Paired Differences } & \multirow{3}{*}{$\mathrm{t}$} & \multirow{3}{*}{ df } & \multirow{3}{*}{ Sig. (2-tailed) } \\
\hline & \multirow{2}{*}{ Mean } & \multirow{2}{*}{ Std. Deviation } & \multirow{2}{*}{ Std. Error Mean } & \multicolumn{2}{|c|}{$\begin{array}{l}95 \% \text { Confidence Interval } \\
\text { of the Difference }\end{array}$} & & & \\
\hline & & & & Lower & Upper & & & \\
\hline FCEO-EVA & 75.96630 & 203.59924 & 12.39066 & 51.57130 & 100.36129 & 6.131 & 269 & 0.000 \\
\hline GEDIV-EVA & 76.20704 & 203.54643 & 12.38744 & 51.81837 & 100.59570 & 6.152 & 269 & 0.000 \\
\hline FEPOR-EVA & 81.73039 & 202.34369 & 12.31424 & 57.48584 & 105.97495 & 6.637 & 269 & 0.000 \\
\hline
\end{tabular}


Table 4. Pearson correlation.

\begin{tabular}{|c|c|c|c|c|c|c|c|c|c|c|c|c|c|}
\hline & & $\begin{array}{c}\text { FCEO_ } \\
08\end{array}$ & $\begin{array}{c}\mathrm{FCEO}_{0} \\
09\end{array}$ & $\begin{array}{c}\mathrm{FCEO}_{-} \\
10\end{array}$ & $\begin{array}{c}\text { GEDIV }_{-} \\
08\end{array}$ & $\begin{array}{c}\text { GEDIV }_{-} \\
09\end{array}$ & $\begin{array}{c}\text { GEDIV } \\
10\end{array}$ & $\begin{array}{c}\text { FEPOR } \\
08\end{array}$ & $\begin{array}{c}\text { FEPOR_ } \\
09\end{array}$ & $\begin{array}{c}\text { FEPOR } \\
10\end{array}$ & $\begin{array}{c}\mathrm{EVA}_{-} \\
08\end{array}$ & $\begin{array}{c}\text { EVA_ } \\
09\end{array}$ & $\begin{array}{c}\text { EVA } \\
10\end{array}$ \\
\hline \multirow{3}{*}{ FCEO_08 } & $\begin{array}{l}\text { Pearson } \\
\text { Correlation }\end{array}$ & 1 & 0.861 & 0.861 & 0.348 & 0.212 & 0.244 & 0.275 & 0.142 & 0.144 & -0.024 & 0.116 & 0.084 \\
\hline & $\begin{array}{c}\text { Sig. } \\
\text { (2-tailed) }\end{array}$ & & 0.000 & 0.000 & 0.001 & 0.045 & 0.020 & 0.009 & 0.181 & 0.174 & 0.821 & 0.276 & 0.430 \\
\hline & $\mathrm{N}$ & 90 & 90 & 90 & 90 & 90 & 90 & 90 & 90 & 90 & 90 & 90 & 90 \\
\hline \multirow{3}{*}{ FCEO_09 } & $\begin{array}{l}\text { Pearson } \\
\text { Correlation }\end{array}$ & 0.861 & 1 & 1.000 & 0.299 & 0.284 & 0.317 & 0.206 & 0.197 & 0.196 & -0.017 & 0.099 & 0.076 \\
\hline & $\begin{array}{c}\text { Sig. } \\
\text { (2-tailed) }\end{array}$ & 0.000 & & 0.000 & 0.004 & 0.007 & 0.002 & 0.052 & 0.062 & 0.064 & 0.874 & 0.353 & 0.476 \\
\hline & $\mathrm{N}$ & 90 & 90 & 90 & 90 & 90 & 90 & 90 & 90 & 90 & 90 & 90 & 90 \\
\hline \multirow{3}{*}{ FCEO_10 } & $\begin{array}{c}\text { Pearson } \\
\text { Correlation }\end{array}$ & 0.861 & 1.000 & 1 & 0.299 & 0.284 & 0.317 & 0.206 & 0.197 & 0.196 & -0.017 & 0.099 & 0.076 \\
\hline & $\begin{array}{c}\text { Sig. } \\
\text { (2-tailed) }\end{array}$ & 0.000 & 0.000 & & 0.004 & 0.007 & 0.002 & 0.052 & 0.062 & 0.064 & 0.874 & 0.353 & 0.476 \\
\hline & $\mathrm{N}$ & 90 & 90 & 90 & 90 & 90 & 90 & 90 & 90 & 90 & 90 & 90 & 90 \\
\hline \multirow{3}{*}{ GEDIV_08 } & $\begin{array}{l}\text { Pearson } \\
\text { Correlation }\end{array}$ & 0.348 & 0.299 & 0.299 & 1 & 0.839 & 0.831 & 0.847 & 0.754 & 0.656 & 0.010 & 0.225 & 0.004 \\
\hline & $\begin{array}{c}\text { Sig. } \\
\text { (2-tailed) }\end{array}$ & 0.001 & 0.004 & 0.004 & & 0.000 & 0.000 & 0.000 & 0.000 & 0.000 & 0.929 & 0.033 & 0.974 \\
\hline & $\mathrm{N}$ & 90 & 90 & 90 & 90 & 90 & 90 & 90 & 90 & 90 & 90 & 90 & 90 \\
\hline \multirow{3}{*}{ GEDIV_09 } & $\begin{array}{l}\text { Pearson } \\
\text { Correlation }\end{array}$ & 0.212 & 0.284 & 0.284 & 0.839 & 1 & 0.895 & 0.726 & 0.845 & 0.742 & 0.100 & 0.212 & 0.084 \\
\hline & $\begin{array}{c}\text { Sig. } \\
\text { (2-tailed) }\end{array}$ & 0.045 & 0.007 & 0.007 & 0.000 & & 0.000 & 0.000 & 0.000 & 0.000 & 0.349 & 0.045 & 0.432 \\
\hline & $\mathrm{N}$ & 90 & 90 & 90 & 90 & 90 & 90 & 90 & 90 & 90 & 90 & 90 & 90 \\
\hline \multirow{3}{*}{ GEDIV_10 } & $\begin{array}{l}\text { Pearson } \\
\text { Correlation }\end{array}$ & 0.244 & 0.317 & 0.317 & 0.831 & 0.895 & 1 & 0.761 & 0.835 & 0.829 & 0.013 & 0.261 & 0.178 \\
\hline & $\underset{\text { Sig. }}{\text { (2-tailed) }}$ & 0.020 & 0.002 & 0.002 & 0.000 & 0.000 & & 0.000 & 0.000 & 0.000 & 0.902 & 0.013 & 0.093 \\
\hline & $\mathrm{N}$ & 90 & 90 & 90 & 90 & 90 & 90 & 90 & 90 & 90 & 90 & 90 & 90 \\
\hline \multirow{3}{*}{ FEPOR_08 } & $\begin{array}{c}\text { Pearson } \\
\text { Correlation }\end{array}$ & 0.275 & 0.206 & 0.206 & 0.847 & 0.726 & 0.761 & 1 & 0.911 & 0.813 & -0.012 & 0.225 & 0.074 \\
\hline & $\begin{array}{c}\text { Sig. } \\
\text { (2-tailed) }\end{array}$ & 0.009 & 0.052 & 0.052 & 0.000 & 0.000 & 0.000 & & 0.000 & 0.000 & 0.913 & 0.033 & 0.490 \\
\hline & $\mathrm{N}$ & 90 & 90 & 90 & 90 & 90 & 90 & 90 & 90 & 90 & 90 & 90 & 90 \\
\hline \multirow{3}{*}{ FEPOR_09 } & $\begin{array}{l}\text { Pearson } \\
\text { Correlation }\end{array}$ & 0.142 & 0.197 & 0.197 & 0.754 & 0.845 & 0.835 & 0.911 & 1 & 0.928 & 0.044 & 0.219 & 0.116 \\
\hline & $\begin{array}{c}\text { Sig. } \\
\text { (2-tailed) }\end{array}$ & 0.181 & 0.062 & 0.062 & 0.000 & 0.000 & 0.000 & 0.000 & & 0.000 & 0.683 & 0.038 & 0.275 \\
\hline & $\mathrm{N}$ & 90 & 90 & 90 & 90 & 90 & 90 & 90 & 90 & 90 & 90 & 90 & 90 \\
\hline \multirow{3}{*}{ FEPOR_10 } & $\begin{array}{l}\text { Pearson } \\
\text { Correlation }\end{array}$ & 0.144 & 0.196 & 0.196 & 0.656 & 0.742 & 0.829 & 0.813 & 0.928 & 1 & 0.026 & 0.225 & 0.155 \\
\hline & $\begin{array}{c}\text { Sig. } \\
\text { (2-tailed) }\end{array}$ & 0.174 & 0.064 & 0.064 & 0.000 & 0.000 & 0.000 & 0.000 & 0.000 & & 0.809 & 0.033 & 0.145 \\
\hline & $\mathrm{N}$ & 90 & 90 & 90 & 90 & 90 & 90 & 90 & 90 & 90 & 90 & 90 & 90 \\
\hline
\end{tabular}


Continued

\begin{tabular}{|c|c|c|c|c|c|c|c|c|c|c|c|c|c|}
\hline \multirow{3}{*}{ EVA_08 } & $\begin{array}{l}\text { Pearson } \\
\text { Correlation }\end{array}$ & -0.024 & -0.017 & -0.017 & 0.010 & 0.100 & 0.013 & -0.012 & 0.044 & 0.026 & 1 & 0.174 & 0.002 \\
\hline & $\begin{array}{c}\text { Sig. } \\
\text { (2-tailed) }\end{array}$ & 0.821 & 0.874 & 0.874 & 0.929 & 0.349 & 0.902 & 0.913 & 0.683 & 0.809 & & 0.102 & 0.987 \\
\hline & $\mathrm{N}$ & 90 & 90 & 90 & 90 & 90 & 90 & 90 & 90 & 90 & 90 & 90 & 90 \\
\hline \multirow{3}{*}{ EVA_09 } & $\begin{array}{l}\text { Pearson } \\
\text { Correlation }\end{array}$ & 0.116 & 0.099 & 0.099 & 0.225 & 0.212 & 0.261 & 0.225 & 0.219 & 0.225 & 0.174 & 1 & 0.603 \\
\hline & $\begin{array}{c}\text { Sig. } \\
\text { (2-tailed) }\end{array}$ & 0.276 & 0.353 & 0.353 & 0.033 & 0.045 & 0.013 & 0.033 & 0.038 & 0.033 & 0.102 & & 0.000 \\
\hline & $\mathrm{N}$ & 90 & 90 & 90 & 90 & 90 & 90 & 90 & 90 & 90 & 90 & 90 & 90 \\
\hline \multirow{3}{*}{ EVA_10 } & $\begin{array}{l}\text { Pearson } \\
\text { Correlation }\end{array}$ & 0.084 & 0.076 & 0.076 & 0.004 & 0.084 & 0.178 & 0.074 & 0.116 & 0.155 & 0.002 & 0.603 & 1 \\
\hline & $\begin{array}{c}\text { Sig. } \\
\text { (2-tailed) }\end{array}$ & 0.430 & 0.476 & 0.476 & 0.974 & 0.432 & 0.093 & 0.490 & 0.275 & 0.145 & 0.987 & 0.000 & \\
\hline & $\mathrm{N}$ & 90 & 90 & 90 & 90 & 90 & 90 & 90 & 90 & 90 & 90 & 90 & 90 \\
\hline
\end{tabular}

that EVA is negatively correlated to the Female CEO status in 2008 and insignificant in 2009 and 2010. EVA is also insignificant with presence of female director in board for 2008, 2009 and 2010. EVA is negatively correlated with high proportionate of female directors in board in 2008 but on the 2009 and 2010 is correlated insignificantly.

Table 5 shows that, the adjusted R-squared for the regression is 0.013 , which indicates that the equation is reliable. All the independent variables are significant at the $1 \%, 5 \%$ and $10 \%$ level. The results clearly indicate that the firm performance (EVA) is not significantly correlated to the female status of CEO, presence of female director in board and ratio of female directors in board.

In conclusion, based on our sample and analysis, our findings do not provide evidence that there is a relation between board gender diversity and firm performance. The results revealed that the presence of females in board is not more than an emblematical role but their contribution towards the good governance is not subsisting in Pakistan. Apparently in Pakistan boardrooms having (more) women on board of directors do not result in a better firm performance. The results are in line with most findings in previous European studies (Randoy et al. [27], Rose [39], Marinova et al. [37]).

The corporate landscape of Pakistan is different from the European context and the presence of the female directors on the board and the selection criteria of different gender are also different from the European constitution.

\section{Conclusions}

The role of females as board members and top corporate executive in a company, CEO, in driving firm performance has become a very topical issue, especially in the
Table 5. Regression analysis.

\begin{tabular}{|c|c|c|c|c|c|}
\hline & \multicolumn{2}{|c|}{$\begin{array}{l}\text { Unstandardized } \\
\text { Coefficients }\end{array}$} & \multirow{2}{*}{$\begin{array}{c}\text { Standardized } \\
\text { Coefficients } \\
\text { Beta }\end{array}$} & \multirow[t]{2}{*}{$\mathrm{t}$} & \multirow{2}{*}{ Sig. } \\
\hline & B & Std. Error & & & \\
\hline (Constant) & -94.575 & 14.490 & & -6.527 & 0.000 \\
\hline FCEO & 30.338 & 68.958 & 0.028 & 0.440 & 0.660 \\
\hline GEDIV & 40.271 & 52.127 & 0.089 & 0.773 & 0.440 \\
\hline FEPOR & 1.092 & 2.039 & 0.060 & 0.536 & 0.593 \\
\hline \multicolumn{6}{|c|}{ Dependent Variable: EVA } \\
\hline \multicolumn{3}{|c|}{$\mathrm{R}$} & \multicolumn{3}{|c|}{0.153} \\
\hline \multicolumn{3}{|c|}{ R Square } & \multicolumn{3}{|c|}{0.024} \\
\hline \multicolumn{3}{|c|}{ Adjusted R Square } & \multicolumn{3}{|c|}{0.013} \\
\hline
\end{tabular}

current times of economic catastrophe in which largely attributed to unsound risk management practices, there is debate if the global economic picture would have looked less grim, had there been more women on boards of directors in the distressed financial institutions. The proponents refer in this respect to the fact that women are more risk-averse and claim that more gender diverse corporate teams will help bring the global economy back on track. These arguments strongly relate to the business case for board gender diversity, which has been investigated empirically in this paper. As such the paper adds to the limited western evidences on the effect of board gender diversity on firm performance. Drawing on the development in organizational strategy and corporate governance over recent years, which approaches women's representation in top corporate positions as a value-driver, the hypothesis in our study is that board gender diversity 
will lead to positive firm performance effects.

Rather than providing final conclusion, this study should be considered a useful starting point for further research. Future studies may include more variables than our study. In addition, it seems useful to extend samples by including non-listed companies. Finally, future research should focus on more than 3 years panel data in order to fine the consistent effect of gender diversity on firm performance. If gender-related performance effects can be traced over several years, the quality and implications of the analysis will improve considerably, as dynamic factors will also be captured in the relationship. The presence of female directors in the board ensure the right mixture of the board with the two genders one side but the profitability is another matter which leads to many certain and uncertain factors. The membership of female independent directors in the board ensures the professional standard as well the God talented skills of female genders like, disciple, etiquette and erudition.

Furthermore, no study has been conducted to scrutinize the effects of gender diversity on firm performance in Pakistan but in most empirical studies wide-reaching so far, including the studies described in this paper, the business case is investigated on a rather general level without examining actual differences between male and female board members and the dynamics within the board. The scarcity of research on the underlying mechanisms and moderating effects in the relationship between board gender diversity and firm performance pinpoints the need for more efforts in this direction.

\section{REFERENCES}

[1] D. S. Langdon, T. M. McMenamin and T. J. Krolik, "US Labor Market in 2001: Economy Enters a Recession," Monthly Labor Review, Vol. 125, No. 2, 2002, pp. 3-33.

[2] Bergen Von, B. Soper and J. A. Parnell, "Workforce Diversity and Organizational Performance," Equal Opportunities International, Vol. 24, No. 3-4, 2005, pp. 1-16

[3] Z. Burgess and P. Tharenou, "Women Board Directors: Characteristics of the Few," Journal of Business Ethics, Vol. 37, No. 1, 2002, pp. 39-49. doi:10.1023/A:1014726001155

[4] A. J. Hillman, A. A. Canella and I. C. Harris, "Women and Racial Minorities in the Boardroom: How Do Directors Differ?" Journal of Management, Vol. 28, No. 6, 2002, pp. 747-763.

[5] C. Daily, S. Certo and D. Dalton, "A Decade of Corporate Women: Some Progress in the Boardroom, None in the Executive Suite," Strategic Management Journal, Vol. 20, No. 1, 1999, pp. 93-99.

doi:10.1002/(SICI)1097-0266(199901)20:1<93::AID-SM $\mathrm{J} 18>3.0 . \mathrm{CO} ; 2-7$

[6] M. L. Maznevski, "Understanding Our Differences: Performance in Decision-Making Groups with Diverse Members," Human Relations, Vol. 47, No. 5, 1994, pp. 531-

\section{2. doi:10.1177/001872679404700504}

[7] F. Milliken and L. Martins, "Searching for Common Threads: Understanding the Multiple Effects of Diversity in Organizational Groups," Academy of Management Review, Vol. 21, No. 2, 1996, pp. 402-434.

[8] L. Pelled, "Demographic Diversity, Conflict and Work Group Outcomes: An Intervening Process Theory," Organization Science, Vol. 7, No. 6, 1996, pp. 615-631.

[9] W. Boeker, "Executive Migration and Strategic Change: The Effect of Top Manager Movement on Product-Market Entry," Administrative Science Quarterly, Vol. 42, No. 2, 1997, pp. 213-237. doi:10.2307/2393919

[10] W. Watson, L. Johnson and D. Merritt, "Team Orientation, Self-Orientation, and Diversity in Task Groups: Their Connection to Team Performance over Time," Group and Organization Management, Vol. 23, No. 2, 1998, pp. 161-189. doi:10.1177/1059601198232005

[11] M. Kilduff, R. Angelmar and A. Mehra, “Top Management-Team Diversity and Firm Performance: Examining the Role of Cognitions," Organization Science, Vol. 11, 2000, pp. 21-34. doi:10.1287/orsc.11.1.21.12569

[12] R. Petersen, "The Management of a Diverse Workforce in the Business Environment of Israel and Possible Applications for South Africa, Dissertation Abstracts International Section B," The Sciences and Engineering, Vol. 60, 2002, p. 4284.

[13] T. Timmerman, "Racial Diversity, Age Diversity, Interdependence, and Team Performance," Small Group Research, Vol. 31, No. 5, 2000, pp. 592-606. doi:10.1177/104649640003100505

[14] M. Conyon and C. Mallin, "Women in the Boardroom: Evidence from Large UK Companies," Corporate Governance, Vol. 5, No. 3, 1997, pp. 112-117. doi:10.1111/1467-8683.00051

[15] D. Bilimoria, "Building the Business Case for Women Corporate Directors," In: R. Burke and M. Mattis, Eds., Women on Corporate Boards of Directors, Kluwer Academic, Norwell, 2000, pp. 25-40.

[16] M. C. Mattis, "Women Corporate Directors in the United States," In: R. Burke and M. Mattis, Eds., Women on Corporate Boards of Directors, Kluwer Academic, Netherlands, 2000, pp. 239-251.

[17] M. Becht, P. Bolton, and A. Röell, "Corporate Governance and Control”, ECGI-Finance Working Paper \# 02, 2002. http://ssrn.com/abstract=343461

[18] B. E. Hermalin and M. S. Weisbach, "Boards of Directors as an Endogenously Determined Institution: A Survey of the Economic Literature," Economic Policy Review, Vol. 9, No. 1, 2003, pp. 7-26.

[19] Ø. Bøhren and R. Ø. Strøm, "Aligned, Informed, and Decisive: Characteristics of Value-Creating Boards," Ljubljana Meetings Paper, 2007. http://ssrn.com/abstract $=966407$

[20] D. A. Carter, B. J. Simkins and W. G. Simpson, "Corporate Governance, Board Diversity and Firm Value," The Financial Review, Vol. 38, No. 1, 2003, pp. 33-53. doi:10.1111/1540-6288.00034 
[21] D. A. Carter, F. P. D’Souza, B. J. Simkins and W. G. Simpson, "The Diversity of Corporate Board Committees and Financial Performance," 2008. http://ssrn.com/abstract $=1106698$

[22] S. E. Jackson, "Consequence of Group Composition for the Interpersonal Dynamics of Strategic Issue Processing," In: P. Shrivastava, A. Huff and J. Dutton, Eds., Advances in Strategic Management, Vol. 8, JAI Press, Greenwich, 1992, pp. 345-382.

[23] N. Smith, V. Smith and M. Verner, "Do Women in Top Management Affect Firm Performance? A Panel Study of 2500 Danish Firms," International Journal of Productivity and Performance Management, Vol. 55, No. 7, 2006, pp. 569-593. doi:10.1108/17410400610702160

[24] D. Bilimoria and S. K. Piderit, "Board Committee Membership: Effects of Sex-Based Bias," Academy of Management Journal, Vol. 37, No. 6, 1994, pp. 1453-1477. doi: $10.2307 / 256795$

[25] S. Zahra and W. Stanton, "The Implications of Board of Directors' Composition on Corporate Strategy and Performance," International Journal of Management, Vol. 5, No. 2, 1998, pp. 229-236.

[26] C. Francoeur, R. Labelle and B. Sinclair-Desgagné, "Gender Diversity in Corporate Governance and Top Management," Journal of Business Ethics, Vol. 81, No. 1, 2008, pp. 83-95. doi:10.1007/s10551-007-9482-5

[27] T. Randøy, S. Thomsen and L. Oxelheim, "A Nordic Perspective on Corporate Board Diversity," Paper Presented at European International Business Academy Annual Conference, Fribourg, 2006.

[28] E. Kang, D. K. Ding and C. Charoenwong, "Investor Reaction to Women Directors," Journal of Business Research, Vol. 63, No. 8, 2010, pp. 888-894. doi:10.1016/j.jbusres.2009.06.008

[29] M. Levi, K. Li and F. Zhang, "Mergers and Acquisitions: The Role of Board Gender Diversity," 2008. http://ssrn.com/abstract=1123735
[30] S. Sudarsanam and J. Huang, "Gender Diversity in US Top Management: Impact on Risk-Taking and Acquirer Performance," 2007. http://www.efmaefm.org

[31] U. Siddharta, "Economic Value Added: Value Creation Measurement of Companies," Usahawan, April 1997.

[32] P. Mohanty, "Modified TVA Based Performance Evaluation," Management Review, Vol. 18, No. 3, 2006, pp. 265-273.

[33] T. Copeland and A. Dolgoff, "Expectations-Based Management," Journal of Applied Corporate Finance, Vol. 18, No. 2, 2006, pp. 82-97. doi:10.1111/j.1745-6622.2006.00089.x

[34] A. Kaur and K. Pal, "Awareness of Economic Value Added among Indian Corporate Managers: Evidences from a Primary Survey," Journal of Applied Finance, Vol. 14, No. 8, pp. 53-65.

[35] S. F. O’Byrne and S. D. Young, "Incentives and Investor Expectations," Journal of Applied Corporate Finance, Vol. 18, No. 2, 2006, pp. 98-105. doi:10.1111/j.1745-6622.2006.00090.x

[36] L. T. Pohlen and J. B. Coleman, "Evaluating Internal Operations and supply Chain Performance Using EVA and ABC," Advance Management Journal, Vol. 70, No. 2, 2005, pp. 45-58.

[37] J. Marinova, J. Plantenga and C. Remery, "Gender Diversity and Firm Performance: Evidence from Dutch and Danish Boardrooms," Koopmans Research Institute, Discussion Paper Series 10-03, 2008.

[38] D. Yermack, "Higher Market Valuation of Companies with a Small Board of Directors," Journal of Financial Economics, Vol. 40, No. 2, 1996, pp. 185-211. doi:10.1016/0304-405X(95)00844-5

[39] C. Rose, "Does Female Board Representation Influence Firm Performance? The Danish Evidence," Corporate Governance, Vol. 15, No. 2, 2007, pp. 404-413. doi:10.1111/j.1467-8683.2007.00570.x 